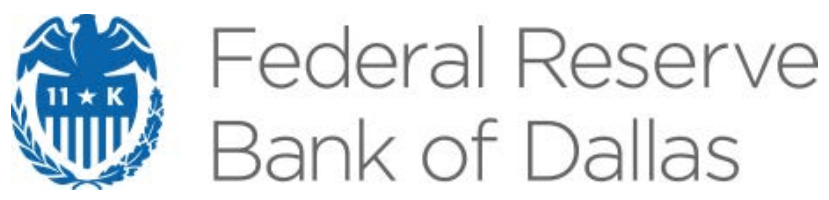

\title{
Inflation and the Gig Economy: Have the Rise of Online Retailing and Self-Employment Disrupted the Phillips Curve?
}

John V. Duca

\section{Working Paper 1814}

Research Department

https://doi.org/10.24149/wp1814

Working papers from the Federal Reserve Bank of Dallas are preliminary drafts circulated for professional comment. The views in this paper are those of the authors and do not necessarily reflect the views of the Federal Reserve Bank of Dallas or the Federal Reserve System. Any errors or omissions are the responsibility of the authors. 


\title{
Inflation and the Gig Economy: Have the Rise of Online Retailing and Self-Employment Disrupted the Phillips Curve?*
}

\author{
John V. Duca ${ }^{\dagger}$
}

November 16, 2018

\begin{abstract}
During the recovery from the Great Recession, inflation did not reach the central bank's 2 percent objective as quickly as many models had predicted. This coincided with increases in online shopping, which arguably made retail markets more contestable and damped retail inflation. This hypothesis is tested using data on the online share of retail sales, which are incorporated into an econometric model. Results imply that the rise of online retail has flattened the Phillips Curve, reducing the sensitivity of inflation to unemployment rate changes. Improvement in fit from just including the online share is tiny-so far. Other results indicate that market-based price indexes are more sensitive to unemployment than measures such as core PCE, which puts a sizable weight on items with imputed prices that may slowly adjust to market conditions. Further, measures of online sales that internalize substitution between online and traditional mail order sales better help track the impact of online sales on inflation dynamics.

A complementary factor is the "gig" economy and the rise of self-employment, which by reducing the bargaining power of labor, could lower the natural rate of unemployment. Model performance and fits are improved using a hybrid approach in which the rise of online sales can flatten the slope of the Phillips Curve by reducing retail pricing power and the prevalence of gig or self-employment can lower the natural rate of unemployment.

By omitting important structural changes in both goods and labor markets, conventional Phillips Curve models have failed to track how the rise of online retailing has flattened the Phillips Curve and how the rise of the gig economy (selfemployment) has lowered the natural rate of unemployment. One notable difference between the price-price and wage-price results is that the combined effects of online shopping and self-employment are more notable on wage inflation than on price inflation. This could plausibly reflect that improvements in information technology may have undermined the pricing power of workers in labor markets to a greater degree than they have affected the pricing power of producers in goods markets.
\end{abstract}

Keywords: gig economy, self-employment, online sales, inflation, unemployment, wages, Phillips Curve

JEL Codes: E31, L10, J30

\footnotetext{
*I thank Jason Saving and Michael Weiss for comments and suggestions. I also thank Lawrence Katz and Alan Krueger for kindly and quickly sharing tax data from their recent NBER working paper. The views expressed are those of the author and do not necessarily reflect those of the Federal Reserve Bank of Dallas or the Board of Governors of the Federal Reserve System. Any remaining errors are solely my own.

†John V. Duca, Oberlin College, Department of Economics, jduca@oberlin.edu and Federal Reserve Bank of Dallas, john.v.duca@dal.frb.org
} 


\section{Introduction}

Since the Great Recession, U.S. inflation has behaved differently than in earlier expansions in several ways. First, inflation and wages did not fall by as much during the Great Recession, as suggested by the large and persistent jump in unemployment (see Hall, 2011). Second, since the subsequent return of unemployment to low levels, the recovery of inflation has been more muted relative to the experience of earlier economic expansions that were accompanied by declines in the headline unemployment rate to unusually low levels. Third, wage growth has been also been unusually subdued amid indications that the headline unemployment rate has understated labor slack and that the employment status of more workers has become more contingent. This pattern suggests that variation in economic slack has taken longer to affect inflation (the Phillips Curve has become flatter) and that the natural rate of unemployment has fallen.

These changes have occurred amid major transformations in both labor and goods markets, characterized by the rise of online shopping and contingent "gig” employment. In efficiency wage frameworks, the adoption of technologies that encourage the use of contingent or just-in-time labor (like gig employment) can be interpreted as lowering the bargaining power of workers, thereby lowering both the natural rate of unemployment and real equilibrium wages (see Campbell (2017), Katz and Krueger (2016), Shapiro and Stiglitz (1984), and Stiglitz (1974)). Alone, the rise of online shopping and gig employment cannot account for the unusual behavior of price and wage inflation. While the rise of gig and part-time employment can help account for signs of a decline in the natural rate of unemployment and for the subdued recovery of wage growth in recent years, they cannot really account for why inflation did not fall more than it did during the Great Recession. And although the rise of online shopping can plausibly 
flatten the slope of the Phillips Curve by reducing local bottlenecks and local retailers' monopoly power, it cannot plausibly account for subdued wage growth and changes in labor market practices outside of the retail sector. Nevertheless, the combination of these shifts in goods and labor market behavior are consistent with both a flattening of the Phillips Curve and a drop in the natural headline rate of unemployment. In addition, both transformations are partially, if not largely, linked to the increased use of information technologies to improve coordination between buyers and sellers in goods markets and the adoption of contingent (just-in-time) labor practices.

There are many dimensions to the gig economy, ranging from whether many jobs will be replaced by advances in robotics and artificial intelligence, to the demise of physical retail shopping stores. Less attention has been paid to how different aspects of the gig economy have affected inflation rates. During the recovery from the Great Recession, inflation has not picked up to the central bank's 2 percent objective as quickly as anticipated and as many models and forecasts had predicted. This development has coincided two important shifts. The first is a sharp rise in online shopping (Figure 1), which arguably made retail markets more contestable, putting downward pressure on retail inflation. ${ }^{1}$ The second has been a continued rise in the share of self-employment, as proxied by the share of individual income tax returns in which filers reported paying the self-employment tax (Figure 2). The latter series limits distortions from filers with incomes too small to qualify for the self-employment tax and those filing business income from tax shelters that shield capital income from taxation, and in this way improves upon

\footnotetext{
${ }^{1}$ Cavallo (2018) has found evidence that increased online shopping has made retail markets more contestable. Guilloux-Nefussi (2015) theoretically shows how lower transactions (iceberg) costs can flatten the slope of the Phillips Curve in a new Keynesian DSGE framework with trade. In the more traditional Phillips Curve specification used here, the estimates are from a post-Volcker disinflation sample period, which limits the effects of changes in credibility as an explanation for changes in inflation dynamics in the more recent period. The sample also limits the channel stressed by Ball, Mankiw, and Romer (1988), in which lower levels of inflation flatten the slope of the Phillips Curve by reducing the frequency of price changes.
} 


\section{Figure 1: Online and NonStore Shares of Retail Sales}

percent of total

retail sales

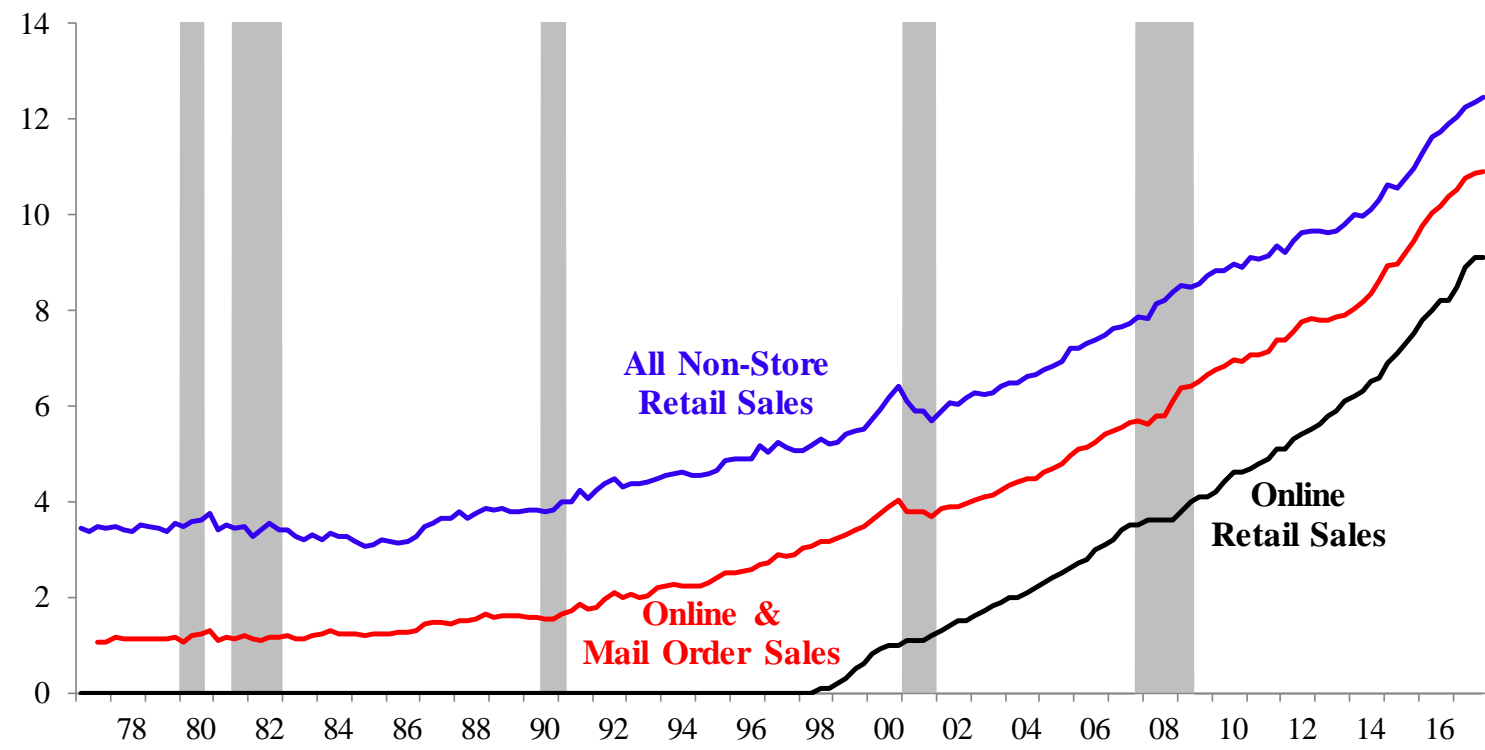

Shaded areas denote NBER-designated recessions. Sources:Census and authors'calculations. No 1992 break adjustment for online (electronic) plus mail-order sales, but a notable break-adjustment was needed to link pre-1992 (SIC-based) and post-1991 NAICS-based data on nonstore retail sales. Author calculations for online retail sales before 1992.

percent, individual

tax returns

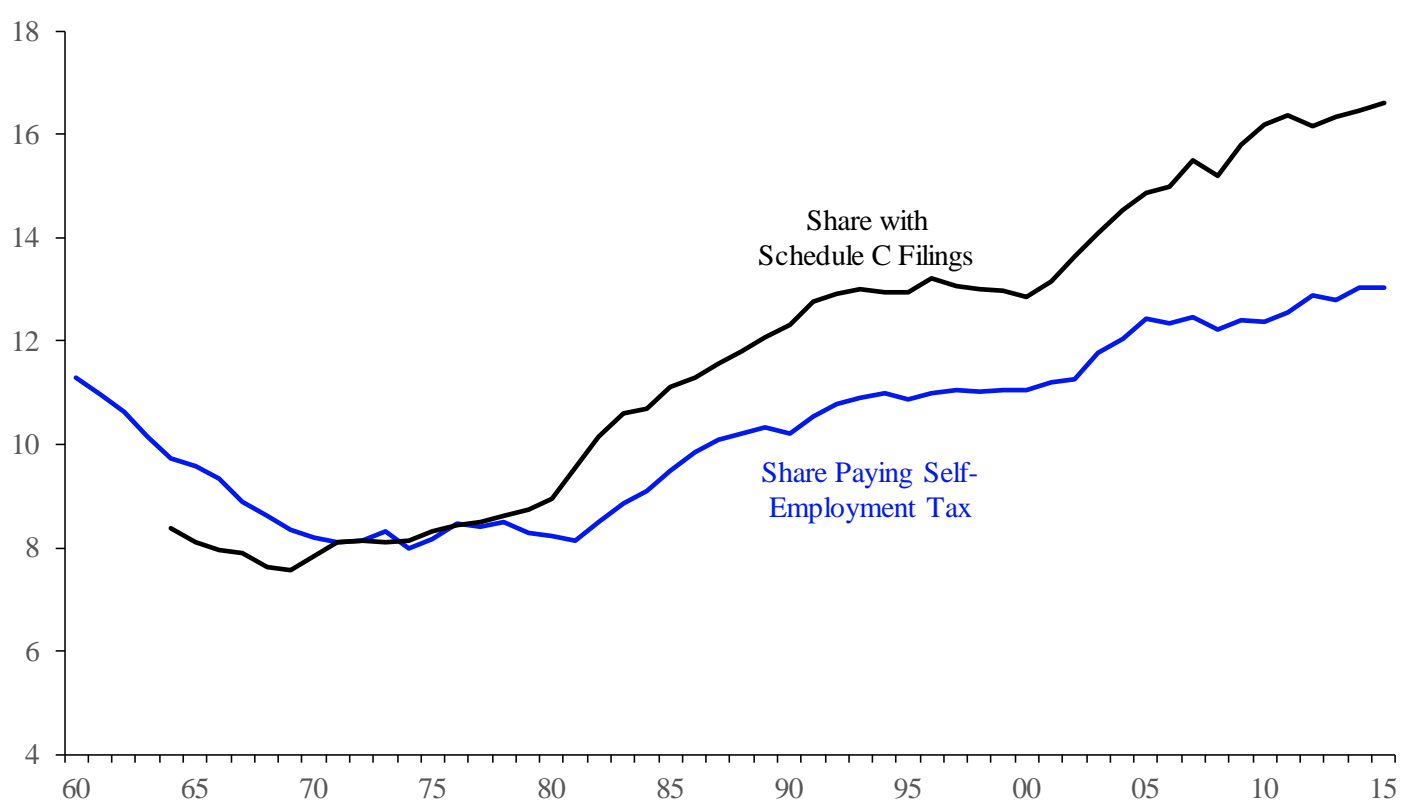

Sources: Katz and Krueger (2016), various annual IRS reports on individual income tax returns, and author's calculations.

Figure 2: The Rise of Self-Employment in the Gig-Economy Era 
the innovative, tax-return based proxy of Katz and Krueger (2016). ${ }^{2}$

This study assesses whether each of these developments and their combination can help account for the muted behavior of core inflation in recent years. In doing so, it investigates what Kuttner and Robinson (2010) could classify as structural explanations for the apparent flattening of the Phillips Curve and apparent decline in the natural rate of unemployment. Results indicate that together the rise of online retailing and self-employment can account for these two types of shifts in the Phillips Curve. Indeed, in samples over which data on online and catalog sales are available (since 1978), the negative estimated coefficient on unemployment is not statistically significant in a conventional model of core PCE inflation, but is in hybrid models accounting for trends in self-employment and online sales. From a broader perspective, this pattern of results is consistent with Friedman's point (1968) that the NAIRU (non-accelerating inflation rate of unemployment) and its effect on inflation depend on the complete set of microeconomic relationships in goods and labor markets and Friedman's (1978) further point that the natural rate of unemployment "is not a numerical constant but depends on "real" as opposed to monetary factors - the effectiveness of the labor market, the extent of competition or monopoly, the barriers or encouragements to working in various occupations, and so on.”

Nevertheless, model fits are only slightly improved using a hybrid approach in which online sales can alter the slope of the Phillips Curve and the prevalence of gig or selfemployment can alter the natural rate of unemployment. Because the natural rate of unemployment is inferred from the ratio of two coefficients (the constant divided by minus the coefficient on the unemployment rate), higher online sales can flatten the Phillips curve and raise the natural rate via lowering the denominator in its calculation. The indirect inference of the

\footnotetext{
2 Our self-employment proxy is statistically significant in more models of core inflation than the Katz and Krueger proxy, which those authors kindly and readily shared with me.
} 
natural rate in Phillips Curve models, coupled with the recent rise of online sales, makes it difficult to pin down the slope and natural rate effects of the rising importance of online sales and self-employed workers. Thus, while preliminary results imply both that the Phillips Curve has flattened and that the natural rate of unemployment has fallen in recent years, the precise extent to which these effects have occurred will likely be refined with more observations and further improvements to the models. An additional complication is that Phillips Curve models better track core inflation with more significant unemployment rate effects when core price indexes omit government imputations of non-measured prices of core goods and services.

On the whole, findings suggest that both carefully tracking shifts in retail and labor market structure-coupled with adopting a disaggregated approach to modeling core PCE inflation — may be warranted. Such a more detailed and nuanced approach may help researchers and policymakers better understand inflation in periods of changing market structure and practices. To establish these findings, section 2 presents a simple Phillips Curve model and the variables used-including the share of retail sales conducted online and the self-employment share of households - to analyze how online sales could flatten the Phillips curve. Section 3 presents and reviews results from estimating these models. Section 4 then assesses how trends in self-employment and online shopping affect the growth rate of compensation as tracked by the employment cost index. The conclusion then provides broad perspective on the findings and the evolving impact of the emerging gig and online-shopping economy.

\section{Specification and Variables for Modeling the Slope of the Phillips Curve}

This section begins by modifying a standard expectations-augmented Phillips Curve framework for hypothesized effects of online shopping and self-employment on the slope and 
natural rate components. The discussion then turns to how online shopping and self-employment are empirically tracked using consistent time series data.

\subsection{Empirical Specification}

According to the NAIRU framework popularized by Gordon (1977), and based on insights from Friedman (1968) and Phelps (1967, 1968), inflation can be modeled as:

$$
\pi_{t}=\alpha_{0} E_{t-1}\left(\pi_{t}\right)+\gamma\left(U_{t}^{*}-U_{t}\right)
$$

where $E$ is the expectations operator, $\alpha_{0}$ is constrained to equal $1, \gamma>0, U$ is the civilian unemployment rate, and $U^{*}$ is the NAIRU (see Fuhrer, 1995). In this framework, inflation moves one-for-one with expected inflation and rises when the unemployment rate falls below its natural rate, or NAIRU. A variable tracking changes in the real exchange rate value of the dollar (eight-quarter change) is added to control for non-domestic effects. ${ }^{3}$ Although $U^{*}$ is not directly observed, if a constant is added, the NAIRU can be inferred from the following baseline model:

$$
\pi_{t}=\beta_{0}+\beta_{1} U_{t-1}+\sum \alpha_{i} \pi_{t-1}+\beta_{2} R E R 8 Q_{t-1}+\varepsilon_{t}
$$

where $\pi=$ inflation measured by a measure of core PCE inflation, RER8Q is the eight-quarter percent change in the broad real exchange rate value of the dollar (Federal Reserve Board), estimates of $\beta_{1}, \beta_{2}$, and $\beta_{3}$ are expected to be negatively signed, and the lagged change in the unemployment rate is included to control for speed effects (changes in unemployment). To avoid simultaneity bias, right-hand side variables are lagged. For internal consistency, the NAIRU specification constrains the sum of coefficients on lagged inflation to equal one since

\footnotetext{
${ }^{3}$ Similar energy price variables had insignificant or non-robust effects in other regressions not shown.
} 
these lags jointly proxy for expected inflation. 12 quarterly lags of inflation are used, which tends to result in clean model residuals in contrast to shorter lag lengths such as 4 or 8 quarters. ${ }^{4}$

In equilibrium, inflation equals its expectation, implying that $U^{*}=-\beta_{0} / \beta_{1}$. For this identification of the latent natural rate to work well, both coefficients should be significant. Other models that replaced or augmented lags of inflation with inflation expectations from the University of Michigan Consumer Sentiment Survey or from the Survey of Professional forecasters gave poor(er) fits. In these models, online shopping effects were weaker, but models without the online shopping variable performed poorly.

To assess the role of online sales and gig employment, the lagged unemployment rate is interacted with the squared share of non-online retail sales $(1-O R S)^{2}$ and the constant is augmented with the share of self-employment $(S E)$ interacted with the squared market share of brick and mortar retailers:

$$
\pi_{t}=\beta_{0}+\beta_{1}\left(1-O R S_{t-1}\right)^{2} U_{t-1}+\beta_{2} S E_{t-1} *\left(1-O R S_{t-1}\right)^{2}+\sum \alpha_{i} \pi_{t-1}+\beta_{3} R E R 8 Q_{t-1}+\varepsilon_{t}
$$

where for a given $\beta_{1}$ and where it is expected that $\beta_{2}<0$.

For a given sized negatively signed $\beta_{1}$, a higher online share lowers the size of the negative impact of unemployment on inflation by reducing the size of $\left(1-O R S_{t-1}\right)^{2}$. In this specification, the slope of the Phillips Curve $\left[=\beta_{1}\left(1-O R S_{t-1}\right)^{2}\right]$ varies with the online share and becomes flatter as online retail sales gain market share.

The non-online share of retail sales can be viewed as positively related to retailers' monopolistic market power, in line with the notion that increased availability of online purchases has made retail markets more contestable and competitive. A decline in the non-online share plausibly is associated with greater competition in product markets, which would be reflected in

\footnotetext{
${ }^{4}$ Some of the lags between t-9 and t-12 were at least marginally significant in the inflation models.
} 
a flatter Phillips' Curve (a weaker stronger response of inflation to changes in the unemployment rate, as demonstrated in the appendix to Duca and VanHoose (2000)). Concentration ratios have been linked to market power, ${ }^{5}$ with evidence (Sleuwaegen and Dehandschutter, 1986), favoring squaring market shares as in the Herfindahl Index. ${ }^{6}$ Because of data limitations, the squared concentration ratio for tracking the monopoly power of non-online retailers as a whole is used rather than a more detailed index summing squared shares of individual retailers.

The natural rate of unemployment in this model reflects both the impact of selfemployment and online shopping. In equilibrium, inflation equals its expectation, implying that $U^{*}=-\left[\beta_{0}+\beta_{2} S E_{t-1} *\left(1-O R S_{t-1}\right)^{2}\right] /\left[\beta_{1} *\left(1-O R S_{t-1}\right)^{2}\right]$. The natural rate in this model reflects both the coefficient on the unemployment rate and the sum $\left[\beta_{0}+\beta_{2} S E_{t-1} *\left(1-O R S_{t-1}\right)^{2}\right]$, with the sum of $\left[\beta_{0}+\beta_{2} S E_{t-1} *\left(1-O R S_{t-1}\right)^{2}\right]$ essentially transforming the numerator of the natural rate from the baseline model into a time-varying term that is decreasing in self-employment. More specifically, higher self-employment will reduce the numerator, thereby lowering the natural rate holding the share of online shopping constant and for given sized coefficients on $\beta_{0}$ and $\beta_{1}$. On the other hand, as online shopping (ORS) rises, although the market power of non-online retailers falls, which directly flattens the Phillips curve slope (i.e., (1-ORS $t-1)^{2}$ falls), this has the effect of raising the implied natural rate, all else the same. Because higher shares of online shopping and self-employment have oppositely signed effects on the natural rate, their combined net effect is an empirical issue.

\subsection{Tracking Online Retail Sales}

Reflecting data availability and substitution with other forms of retailing, the relative share of U.S. online retail sales can be tracked with three measures, each plotted in Figure 1:

\footnotetext{
${ }^{5}$ Saving, 1970, shows conditions under which the Lerner index is related to concentration ratios.

${ }^{6}$ Regressions using the squared non-online share outperformed those using the non-squared share.
} 
online retail sales (ORS), online plus mail-order sales (ORSMO), and nonstore retail sales (NonStore). The first (ORS) are Census readings on the online share of retail sales (1999:q4present), with earlier data inferred as discussed in Appendix A.

There are three possible shortcomings to using the series ORS to estimate eq. (3). First, there is the possibility of errors arising from inferring pre-1999 data points. However, given that the online share of sales was only 0.6 percent in early 1999, the magnitude of such errors is likely to be so small as to have a very limited impact on coefficient estimates. The second shortcoming is that the series ORS is only available over a short sample period for estimating Phillips Curve models, which typically need the data to span a few recessions in order to detect unemployment rate effects on inflation. A third issue is that some of the rise of ORS reflects substitution away from traditional mail-order sales-as reflected by the narrowing of the vertical difference in the retail sales share of mail order plus online sales (the red line) and the share of online sales (the black line) in Figure 1. Such substitution implies that changes in ORS overstate the impact of increased online retailing. For example, official Census data imply that the retail share of mail order sales was 3 percent in 1999:q1—when official online sales data start—and but fell to almost 2 percent ten years later in 2009 .

An alternative addressing all of these shortcomings is tracking the share of retail sales from mail order plus online sales (ORSMO), which internalizes substitution between the two types of sales. Census data using the NAICs industrial classification on such sales are available since 1992, which helps extend the sample. Data using the SIC classification of mail order sales are available from 1977:q4-2000. Fortunately, the implied shares of retail sales from mail order plus online sales overlapping NAICs and SIC are very similar in overlapping years, with the former exceeding the latter by an average of $\$ 10.5$ million or 0.3 percentage points of total retail 
sales in the eight quarters of 1992-93. The differences were so small that the earlier series on mail order sales from 1977:q4 to 1991:q1 were spliced without a break adjustment onto post1992 data to form a continuous series on online retail plus mail order sales for 1977:q4-2017:q4.

Whether the inclusion of mail order sales helps is partly an empirical issue. On the one hand, compared with mail order catalogs, online shopping offers greater information from more photos and product specifications. Traditionally, mail order sales tended to have an advantage over traditional retailing on the basis of reduced the transactions costs covering a wide range of choice. Additionally, mail order sales were more suitable for products that were more homogenous and for which consumers required less information (Michael, 1994). Indeed, as product differentiation rose in the early 1900s, the appeal of mail order sales sagged, spurring some mail order firms, such as Sears, Roebuck and Co., to shift to brick-and-mortar stores (Michael, 1994). Online shopping provides consumers not only with more complete, readily available information than mail order catalogs, but also with an online search experience affecting the utility of a purchase in ways that differed from mail order sales (Kleina, 1998). This consideration implies that online and mail order sales are not very substitutable and favors using the narrow (ORS) over the broader measure (ORSMO).

On the other hand, mail order sales curb local retail monopoly power. Although the small share of mail order sales reflects limited substitutability for differentiated goods, the one-third share decline in the mail order share of retail sales from 3 percent to 2 percent from 1999 to 2009 implies notable substitution between mail order and online sales. This consideration, plus the longer time sample of four decades (1978-2017) of online plus mail order sales versus the two decade sample (1999-2017) for online sales, favors using the broader measure (ORSMO) to track how the online revolution is altering the impact of unemployment rate swings on inflation. 
A third option is the share of retail sales from nonstore retailing (NonStore), which are available since 1967:q1, and which include online and mail order sales. Aside from a longer sample period than available from using ORSMO, another justification is that the main substitution for brick and mortar sales stems from the avoidance of maintaining local, physical stores. Thus, in principle, there might be an advantage to using the non-store share of retail sales over the online plus mail order share.

However, NonStore suffers from two shortcomings with respect to ORSMO. First, it largely differs from ORSMO by including vending machine sales, sales from direct selling firms, and, since 1992, direct sellers of fuel. The last component makes Nonstore date vulnerable to shifts in relative energy prices, thereby introducing some measurement error and noise. Indeed, Figure 1 illustrates that NonStore is visibly noisier than ORSMO. Second, there is a sizable break in definitions stemming from the U.S. shifting how it classifies industries (from SIC to NAICs), which added direct fuel sales to the nonstore category. Splicing the old and new series requires applying an adjustment factor of 43.6 percent to pre-1992 data to make them comparable to post-1991 data. In contrast, there were tiny differences in mail order sales around the transition from SIC to NAICs accounting, necessitating no break adjustment for ORSMO. As with reviewing the relative attractiveness of ORS and ORSMO, the appeal of tracking online sales effects with NonStore versus ORS and ORSMO is an empirical issue. Specifically, the relative appeal depends on whether any net benefits from internalizing substitution among a broader set of non-store types of retailers outweigh the costs of increased measurement error from broadening the measure of ORS used to estimate online effects.

\subsection{Tracking Self-Employment}

Two measures of self-employment are considered. One (SCTax) is a quarterly 
interpolation of 1980-2015 annual data from Katz and Krueger (2016) on the share of self-employed as tracked by the share of tax returns with business tax (schedule C) filings. ${ }^{7}$ The other (SETax) is the quarterly interpolated annual share of tax returns (source: annual IRS reports) in which filers paid self-employment tax (which is incurred for business income that exceeds modest levels. SETax has the relative advantages over SCTax of not counting as predominantly self-employed those with small side incomes or those engaged in passive tax shelters. On the other hand, SCTax may encompass more forms of self-employment that are overlooked by SETax. Using comparable statistics on the share of individual tax returns reporting net business income or losses, both series extend back to $1964{ }^{8}$ Data for 2016 and 2017 are projected using rates of change from 2014-15 in each series.

As illustrated earlier in Figure 2, both series show self-employment rising since 1980, ${ }^{9}$ consistent with a growing gig economy. The broader measure using Schedule C filings shows more of an uptrend than the self-employment-based series. Obviously, both series do not track all forms of self-employment, but they do comprise the main component. Suitable data on alternative forms of self-employment are unavailable either on a continuous basis or over a long enough sample to estimate Phillips Curve models, which practically require samples spanning a few business cycles. With these caveats in mind, the time series patterns in the two gauges of self-employment are used to proxy shifts in the importance of self or gig employment.

\footnotetext{
${ }^{7}$ Abraham, et. al (2017) find that the upward trend in the series from Katz and Krueger is more accurate than the downward to flat trend in the CPS series; essentially, the latter series suffers from misreporting, particularly among certain demographic groups.

${ }^{8}$ Overlapping annual data for 1980-1982 show a consistent 5 percent level difference between the Katz and Krueger series and the share of individual income tax returns with business income. This small adjustment is used to splice earlier readings onto the Katz and Krueger data. There is a large time series break in SCTax between 1963 and 1964, which deterred me from presenting pre-1964 data.

${ }^{9}$ The self-employment tax share trended downward in the 1950s and 1960s.
} 


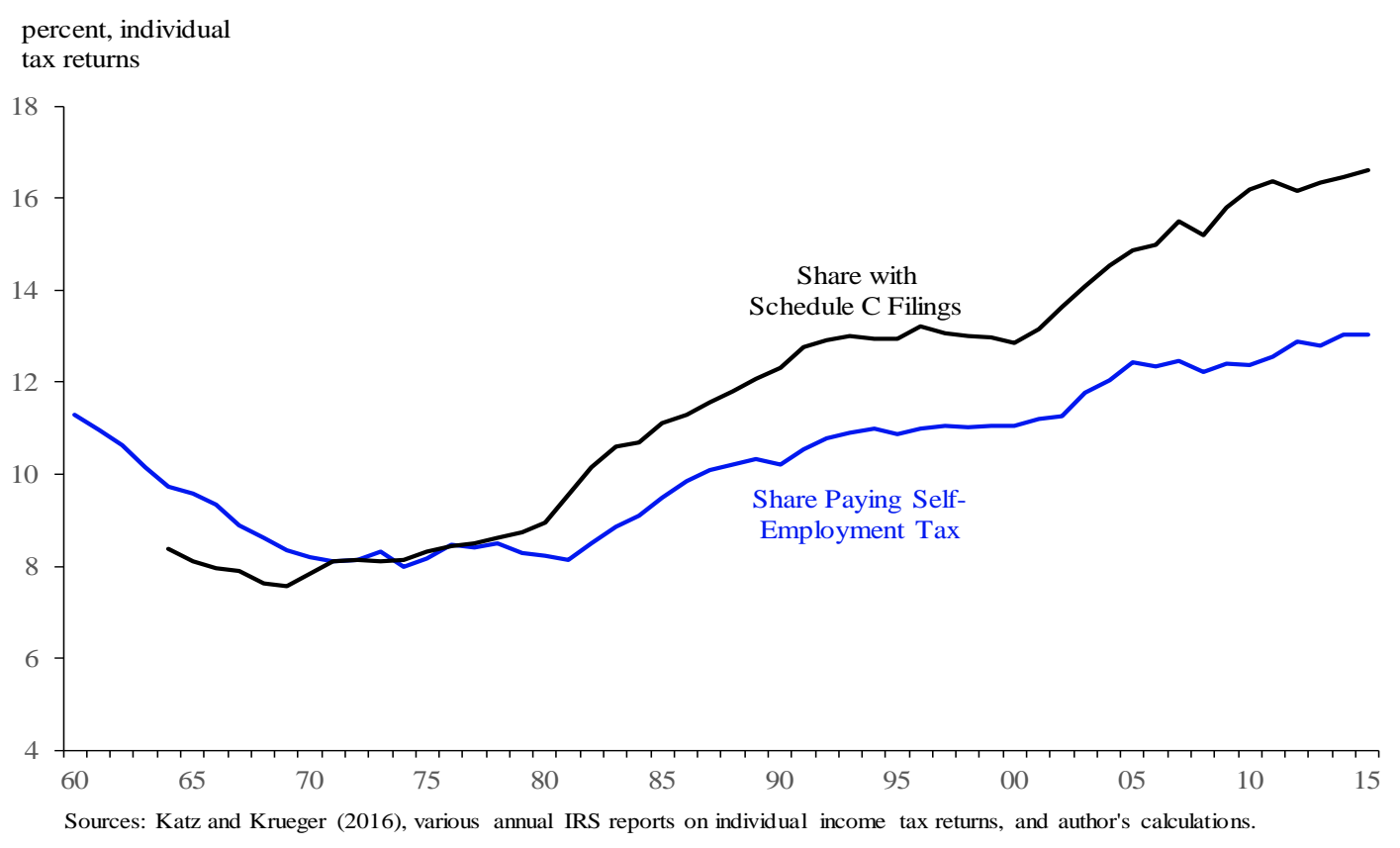

Figure 2: The Rise of Self-Employment in the Gig-Economy Era

\subsection{Two Measures of Core Inflation Are Considered}

Two measures of core inflation are modeled: core PCE inflation and market-based core PCE inflation. Figure 3 plots the year-over-year inflation rates for these series. Aside from analyzing standard core PCE inflation, there are good reasons to consider the market-based measure of core inflation. The total core PCE index includes some component prices that are government administered or regulated (e.g., medical services) or are not market-observed—but are rather imputed by government statisticians. Relative to this benchmark index, the marketbased core PCE inflation offers the benefit of omitting prices of imputed items (e.g., owner's equivalent rent on owner-occupied housing) whose measured prices may be overly smoothed by imputation methods and whose prices are not components of retail sales.

\section{Empirical Results on Core Inflation}

\subsection{Long Sample Regressions Using Core and Market-Based Core PCE Inflation}

Tables 1 and 2 presents results for estimating these core PCE and market-based core 


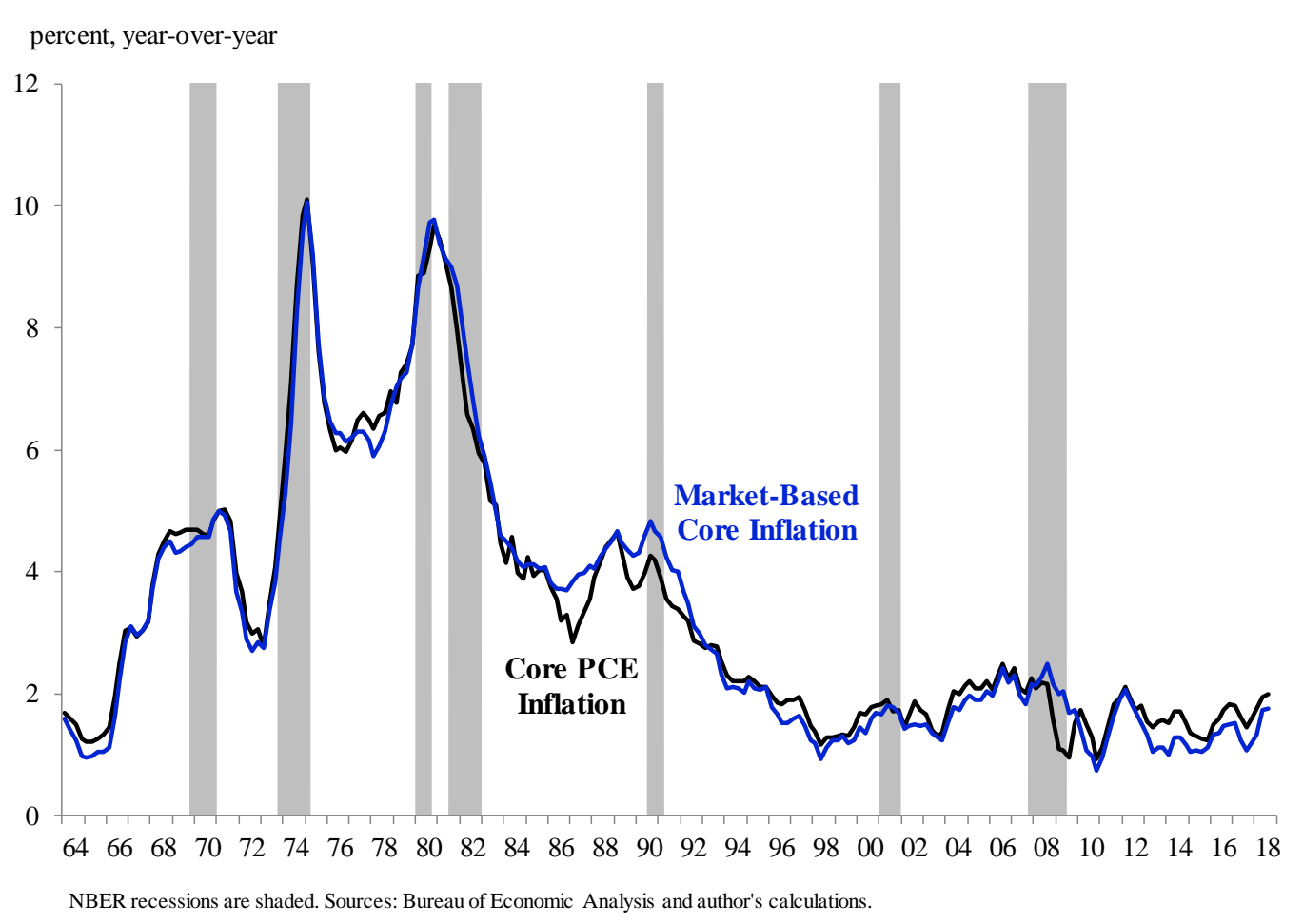

Figure 3: Core and Market-Based Core PCE Inflation Rates

PCE, respectively, using six different models over the sample 1962:q2-2018:q3 and three different models over a pre-Great Recession sample (1962:q2-2018:q3). To avoid overly complicating the tables, the online share of retail sales is tracked with one measure, online retail sales plus mail order sales (ORSMO), and the self-employment share is tracked by the share of tax returns in which self-employment taxes were paid (SETax). In a table available upon request, this combination of measures of the online retail and self-employment shares yielded the best full sample fit among the six different possible combinations. To estimate the models over this long sample, the pre-1977:q3 levels of the online plus catalog were set at their 1977:q4 level. This is a reasonable rule of thumb as the actual share was relatively flat near this level from 1977:q4 to 1985:q4. For robustness, results from a subset of four models for both measures of core PCE inflation are provided in Table 3 and are discussed later. For long sample models, two dummies are added to control for the distortions from the imposition of wage-price controls in 1971 and 
the lifting of most controls in 1973. WPON equals 1 in the first two quarters (1971:q3 and 1971:q4) after the Nixon wage-price controls were imposed in early August 1971, and WPOFFOPEC equals 1 in 1974:q2 and 1974:q3 for the two quarters following the lifting of most of the controls in April 1974. The latter also works to pick up the lagged effect of the OPEC-induced shock to energy prices. These two dummies are similar to the ones used by Gordon (1977) and helps limit miss-specification bias to estimated coefficients.

In Table 1 and Table 2, Model 1 is the baseline model (equation 2), which the full specification in equation (3) reduces to when the online sales and self-employment shares are dropped. Model 2 allows for self-employment (SETax) to vary, but omits tracking any impact of online retail sales. Model 3 re-estimates Model 1, but adjusts the headline (U-3) measure of civilian unemployment for the share of the labor force employed part-time but wishes to work full time. More specifically, this share splices post-1991 data from the monthly household employment survey (reported in the monthly employment report) with break adjustments to earlier data. Then, the resulting share is multiplied by a constant ratio $23 / 35$, reflecting that, on average, part-time employees work 23 hours per week versus 35 for the average worker. This adjustment helps convert the U-3 unemployment rate into a full-time equivalent measure of (under) unemployment. Model 4 uses the U-3 unemployment rate and interacts it with the square of the non-online retail sales variable ${ }^{10}$, but omits an explicit role impact for self-employment. Model 5 estimates the full hybrid specification in equation (5) by explicitly incorporating roles for the shares of online retail sales and self-employment. Model 6 is a variant of Model 5 that replaces the headline unemployment rate with the rate adjusted for part-time employment.

10 Then non-online share equals 100 percent minus the share of retail sales done online or via catalog. 
Several patterns emerge across Models 1-6 of core PCE inflation in Table $1 .^{11}$ First, as expected the estimated coefficients on the unemployment rate, exchange rate, and price control imposition variables are negative and highly significant, and those on the dummy for the lifting of price controls are positive and highly significant. ${ }^{12}$ Second, comparing the baseline and hybrid models, the part-time adjustments to the unemployment rate result in slightly worse model fits over the full sample, implying that the headline unemployment measure is more informative about inflation. Third, the self-employment share is insignificant when the role of online retail sales is ignored (as in Model 2), but is negative and significant when both effects are taken into account in the full-sample model (Model 5) using headline unemployment and the two models estimated over the pre-Great Recession sample (Models 8 and 9). Fourth, ignoring selfemployment, the tracking of online sales alone barely improves model fit (Models 1 vs. 4), with the fit improving somewhat more noticeably when online sales and self-employment effects are tracked (Models 1 vs. 5 and Models 3 vs. 6). Fifth, the implied natural rates in 2018:q3 for the hybrid models are notably lower than in the baseline models for both the headline unemployment rate (4.09 vs. 5.87) and part-time adjusted unemployment rates.

To assess whether the findings only reflected the experience of the Great Recession, the models were re-estimated using a pre-Great Recession sample of 1962:q2 to 2007:q3. To conserve space, Tables 1 and 2 report pre-Great Recession results for Models 1, 5, and 6 in

\footnotetext{
${ }^{11}$ In all the models in Table 1, the t-3 lag of the two-year percent change real exchange rate is used. This lag outperformed the t- 1 and $t-2$ lags, reflecting some delay in the pass-through of exchange rate effects. For the market-based core PCE inflation rate shown in Table 2 and models 5-8 in Table 3, the t-1 lag of the real exchange rate variable is used. The shorter (t-1) lag outperformed other lags, likely reflecting the faster pass-through of exchange rate effects on market-based (observed) prices compared to the broader index that includes imputed prices which may be overly smoothed by imputations. In other runs not shown, interacting the exchange rate with the online sales share did not improve model fit or the significance of the real exchange rate.

${ }^{12}$ The magnitude of the coefficient for the lifting of controls is larger than that on dummy for the imposition of price controls. This is sensible, as the latter captures no only some lagged pass-through effect of the OPEC shock to energy prices, but also the release of inflationary pressures that were artificially repressed from 1971:q3 to 1974:q1.
} 
Models 7, 8, and 9, respectively. The qualitative patterns were very similar, as were many of the quantitative estimates, with two statistically insignificant but noticeable differences. First, the estimated impact of the real exchange rate variable is quantitatively larger in the earlier sample, which may reflect that exchange rate swings were limited during post-2007:q3 period when the monetary policy stances of major central banks were unusually similar. Second, the absolute magnitudes of the estimated coefficients on the constant and the self-employment share are larger in the earlier sample. However, since they are combined when imputing the natural rate of unemployment, together they are similar, as reflected in the implied 2018:q3 levels of the natural rate of unemployment (4.09 from Model 5 vs. 3.83 from Model 8).

Coefficients can be used to illustrate the evolution of the implied natural rate of unemployment and the estimated slope of the Phillips Curve. As shown in Figure 4, the natural rate of unemployment has fallen, according to the hybrid model. and by noticeable amounts—by nearly 1 percentage point between 1990 and 2018, and to levels far below the baseline, constant NAIRU model. The flattening of the Phillips Curve is illustrated in Figure 5, which plots curves at the start of two recessions (1990:q4 and 2007:q4) and for 2018:q3. For every 1 percentage point rise in the unemployment rate, core PCE inflation would have risen by 0.16 percentage points per year in 1990:q4, but only 0.13 percentage points in 2018:q2.

Table 2 reports results for estimating market-based core PCE inflation. ${ }^{13}$ In general, the patterns of results are similar and parallel those of Table 1 for core PCE inflation. One minor difference is that the self-employment share in the full-sample hybrid model (Model 5) is marginally significant instead of being significant with 95 percent confidence, and is less

\footnotetext{
${ }^{13}$ Two minor specification differences are the inclusion of the $\mathrm{t}-1$ change in the unemployment rate in market-based core models (where it is statistically significant versus being highly insignificant in models of overall core PCE inflation) and the shorter time lag on the exchange rate variable in the market-based core models as discussed in footnote number 10 .
} 


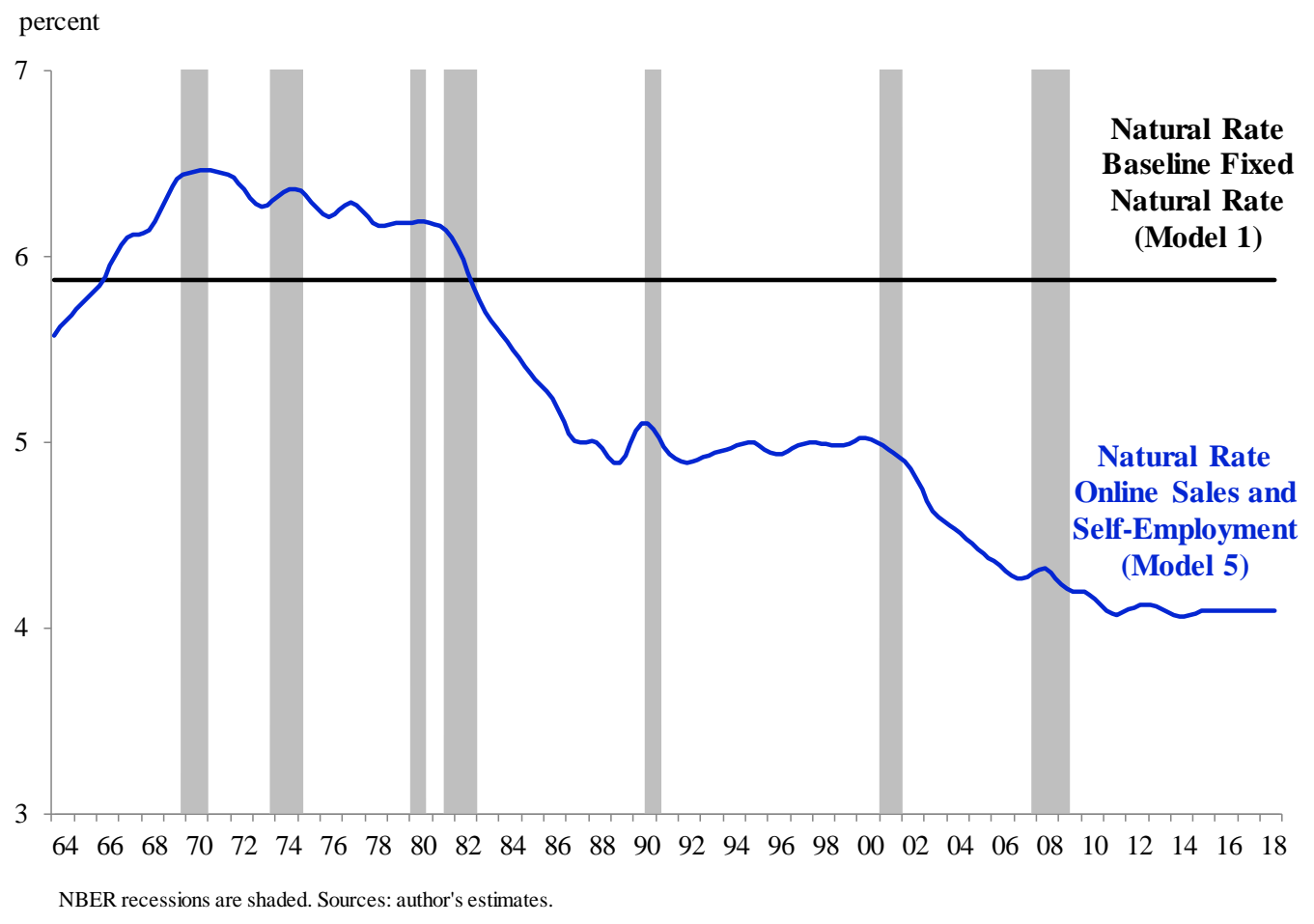

Figure 4: Natural Rate of Unemployment for Core PCE Inflation

Natural rates implied by models 1 and 5 in Table 1 . Source: author's estimates and calculations.

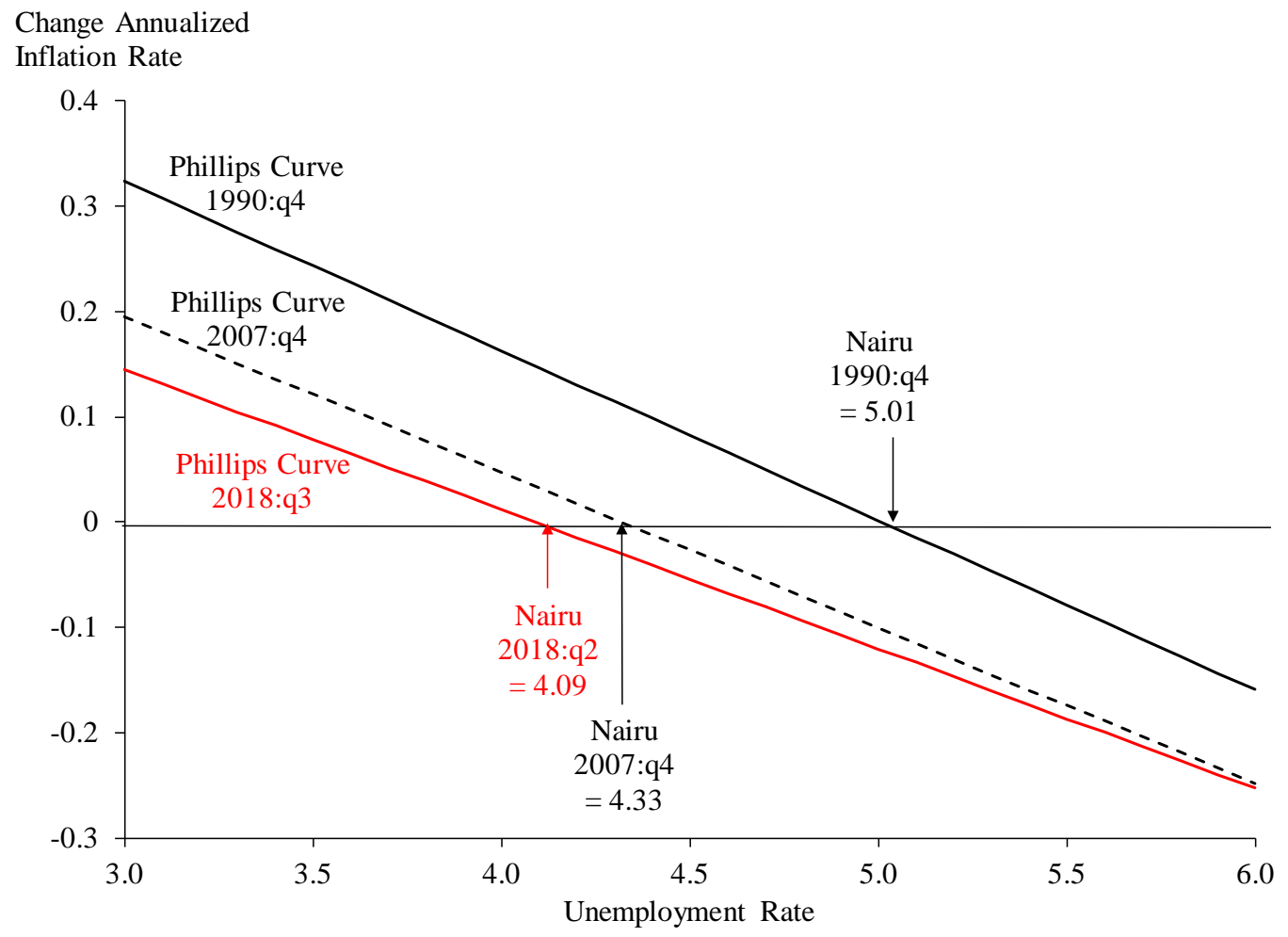

Figure 5: The Evolving Phillips Curve

Notes: Effects implied by Model 5 in Table 1. Source: author's estimates and calculations. 
statistically significant in the pre-Great Recession models. Overall, the modest improvement in model fit of the hybrid model over the baseline model for both measures of core PCE inflation suggest that the impact of online sales and self-employment on inflation is modest and nuanced—at least thus far in models estimated over long sample periods.

\subsection{Shorter Sample Regressions}

Models are also estimated over shorter sample periods since the online plus mail order catalog sales series starts in 1977:q4, implying that models can be estimated with complete data with samples starting in 1978:q1. To conserve space, results from estimating the four models from Tables 1 and 2 that use the headline unemployment rate over a sample 1978:q1-2018:q3 are presented in Table 3. Models 1-4 for core PCE inflation in Table 3 are shorter sample versions of Models 1, 2, 4, and 5 from Table 1, and Models 5-8 for market-based core PCE inflation in Table 3 are shorter sample versions of Models 1, 2, 4, and 5 from Table 2.

Several patterns emerge in Table 3. First, the Phillips Curve framework does not work as well, with the unemployment rate notably less significant and the constant often insignificant. Second, this is particularly the case for the baseline model of core PCE inflation, in which the unemployment rate is only marginally significant and the constant is insignificant. Third, the unemployment rate is significant in the core PCE models incorporating a role for online sales and the constant in those model is at least marginally significant. Fourth, the self-employment share is insignificant in the core PCE models. As before, the model incorporating roles for both online shopping and self-employment fit better than the other models. In a contrast to the core PCE inflation models, coefficient estimates are more consistent with the main driving mechanism underlying the Phillips Curve specifications. In particular, the unemployment rate is has a negative and statistically significant relationships. This is consistent with the concern that 
imputed prices in the core PCE may obscure the impact of slack and other market forces on inflation. Interestingly, neither of the models that allow for only one hybrid model factor-either online sales or self-employment—notably improve the ability to model market-based core PCE inflation. Only when both factors are present is there a noticeable, albeit modest, improvement in fit, with the self-employment share having a negative estimated coefficient that is at least marginally significant. The hybrid specification in Models 4 and 8 in Table 3 imply similar natural rates of unemployment, slightly varying from 3.98 to 4.09 for the 1978:q1-2018:q3 sample shown in Table 3 and being nearly identical at 4.09 for the full sample Model 5 estimates in Tables 1 and 2.

\section{Assessing the Impact on Compensation}

As noted by Gordon (1997), if a structural factor is altering the Phillips Curve relationship for price inflation, it should have a consistent impact on the growth in employee compensation. Accordingly, the roles of online shopping and self-employment for compensation are assessed in wage-price models. In particular, a Phillips Curve approach is used to model the growth rate of the employment cost index (ECI) for private sector workers. Unlike growth in average hourly wages, the ECI is good for tracking compensation costs as it covers both wages and benefits, and by design, is not distorted by shifts in employment across industries.

\subsection{Empirical Specification}

The wage inflation specification models nominal ECI inflation $\left(\pi^{w}\right)$ :

$$
\begin{aligned}
\pi^{w}{ }_{t}= & \beta_{0}+\beta_{1}\left(1-\text { ORS }_{t-1}\right)^{2} U_{t-1}+\beta_{2} S E_{t-1} *\left(1-\text { ORS }_{t-1}\right)^{2}+\sum \alpha_{i} \pi^{p c e} t-1+\beta_{3} \text { REnergy8 }_{t-1} \\
& +\beta_{4} \operatorname{Prod8Q}_{t-1}+\varepsilon_{\mathrm{t}}
\end{aligned}
$$

where the sum of the lagged coefficients on total PCE inflation is constrained to equal 1 for consistency with the natural rate framework. Equation (4) is similar to eq. (3) with four 
differences. First, it includes lags of inflation measured with the overall PCE price deflator $\left(\pi^{p c e}\right)$ to allow for food and energy costs to affect compensation. Second, it shortens the lag length on inflation from 12 to 8 quarters, as there was little information in PCE inflation lagged 9 to 12 quarters. Third, it adds a separate term for energy price inflation (the eight-quarter percent change in PCE energy prices deflated by PCE prices excluding energy) to allow for energy shocks to have some possible negative effect on real compensation growth. ${ }^{14}$ Fourth, it drops the exchange rate variable from equation (3), which proved to be insignificant. Fifth, to control for real increases in compensation stemming from higher productivity growth, it includes the t-1 lag of non-farm productivity growth over the prior 8 quarters (Prod8Q). ${ }^{15}$ The eight-quarter spans used to define the percent changes in real energy prices and productivity correspond to the eight lags on quarterly PCE inflation used to proxy for expected inflation. Finally, reflecting that the ECI is available only in the 1980s with sample periods starting in 1982:q2, the wage inflation models do not include the dummies for the wage-price controls of the early 1970s.

In equilibrium, compensation inflation equals expected PCE price inflation plus an effect of productivity growth on real wages, implying that $U^{*}=-\left[\beta_{0}+\beta_{2} S E t *\left(1-O R S_{t-1}\right)^{2}-\right.$ $\left.\beta_{4} \operatorname{Prod} 8 Q_{t-1}\right] /\left[\beta_{1} *\left(1-O R S_{t-1}\right)^{2}\right]$. This adjustment allows us to compare the natural rate estimates from the price and wage (compensation) inflation models.

\subsection{Estimation Results}

Table 4 reports estimates from nine models corresponding to the nine inflation models in Tables 1 and 2. Across the models, the basic Phillips Curve relationships hold up, with the

\footnotetext{
14 Higher energy prices can feed through to higher compensation via the impact of higher lagged overall PCE inflation, while the negative impact of higher energy prices on wages by lowering the marginal product of labor enters via the lagged eight-quarter percent change in relative consumer (PCE) energy prices.

15 A productivity variable ( $P R O D 8)$ was added in order for the wage equations to be well-behaved, as in Staiger, Stock, and Watson (2001). The span of the productivity term mirrors the 12 quarterly inflation lags without unduly reducing the degrees of freedom by including 12 noisy lags of quarterly productivity growth.
} 
constant and the unemployment rate being highly significant. As in the price inflation models, the self-employment share is insignificant when controlling for the rise of online shopping is omitted, as reflected in Model 3. However, it is highly significant in models controlling for online shopping, with the expected negative sign. As with the price inflation models, when the online shopping is accounted for but not self-employment, there is a modest effect on fit, albeit smaller than in Tables 1 and 2 when one compares Models 1 and 4.

One notable difference is that there is a notable improvement in model fit when both online and self-employment trends are tracked, as reflected by comparing Models 1 and Model 5 (which use headline unemployment) and Model 3 with Model 6 (which use the part-time adjusted unemployment rate). Interestingly, the implied natural rates of unemployment using both unemployment gauges are similar across the price and wage inflation models (for 2018:q3, 4.1 percent in Model 5 in Table 1 versus 3.9 percent for Model 5 in Table 4). As with the price inflation results, model coefficients and values for online and self-employment variables imply that that the slope of the wage-price Phillips Curve has flattened with the rise of online shopping (not shown to conserve space).

Nevertheless, one difference between the price-price and wage-price results is that the combined effects of online shopping and self-employment are more notable on wage inflation than on price inflation. This could plausibly reflect that improvements in information technology may have undermined the pricing power of workers in labor markets to a greater degree than they have affected the pricing power of producers in goods markets. 


\section{Conclusion}

The contemporaneous rise of online shopping and self-employment has coincided with a comparatively slower rise of wage growth and core consumer inflation than conventional Phillips Curve models would have predicted. Evidence indicates that augmenting such models with information about rise in both the online share of retailing and the self-employment share of employment implies that the Phillips Curve has flattened and the natural rate of unemployment has fallen. Together, these effects modestly improve our ability to explain inflation and yield results that are more consistent with the fundamental assumptions of the Phillips Curve than benchmark, non-gig economy models. In addition, results imply that by omitting important structural changes in both goods and labor markets, conventional Phillips Curve models have failed to track how the rise of online retailing has flattened the Phillips Curve and how the rise of the gig economy (self-employment) has lowered the natural rate of unemployment.

Interestingly, these effects have been underway for longer than press accounts may suggest. Nevertheless, because the magnitudes of these effects are modest and the improvement in fit is also modest, the rise of online shopping and self-employment appears unlikely to account for the bulk of unexpected softness in core inflation.

Results highlight the importance of accounting for both the rise of online shopping and self-employment, neither of which alone seem to explain changes in the behavior of inflation. Alone, it is a priori unclear what the net effect of greater online shopping is on the Phillip's Curve. Cavallo (2018) finds that the rise of online shopping has coincided with downward pressures on mark-ups, increased pressure for more uniform pricing, and greater contestability. These developments would tend to lower inflation and by reducing markups, may flatten the slope of the Phillips Curve. On the other hand, Cavallo (2018) also finds faster adjustment of 
prices to cost shocks which may make the Phillips Curve more prone to shift in response to supply shocks and arguably the degree of labor slack. The latter effect could potentially steepen the Phillips Curve and work against the slope-flattening effect of greater online shopping on the behavior of price markups.

However, the Phillips Curve can plausibly become flatter and have a lower natural rate of unemployment when the impacts of both increased online shopping and increased selfemployment are combined. By reducing the bargaining power of workers and making labor markets more contestable, the rise of self-employment imparts downward pressure on compensation and makes labor supply more elastic. This would tend to reduce the impact of labor market slack on costs. Although online shopping induces firms to more quickly pass-on cost pressures, the rise of self-employment and downward pressure on mark-ups can make those cost pressures less sensitive to the unemployment rate. If the latter two effects prevail, the Phillips Curve would both become flatter and reflect a lower natural rate of unemployment, consistent with the current paper's findings.

Nevertheless, likely owing to the limitations of Phillips Curve models to separate slope from natural rate effects in a short sample, the analysis may not precisely parse out how the low inflation of recent years reflects a flattening of the Phillips Curve versus a decline in the natural rate of unemployment. The short sample also limits the ability to distinguish whether online shopping's effects are temporary or long-lasting. Temporary effects may occur if the transition to online retailing induces several one-time downshifts of profit margins in different industries. On the other hand, more-lasting effects in the form of a flatter Phillips Curve may arise if the shift to online retailing makes markets permanently more contestable. For these reasons, 
analysis of gig-economy effects would benefit as more data become available and further research is warranted.

Further improvements in mobile information technology and transportation for delivering goods suggest that online sales will make further inroads. This study's estimates suggest that a further flattening of the Phillips Curve could occur as a result of such continued trends. And these technological improvements, along with advances in artificial intelligence, could make it easier for firms to subcontract more work to the self-employed and to displace more workers with new technology. Results suggest that this could lower the natural rate unless offset by other changes, such as labor laws. From a broader perspective, this study sheds light on a neglected aspect of the innovations driving the rise of the gig economy-namely how they may alter inflation by making product markets more contestable via bolstering online shopping and by reducing worker bargaining power and firms’ turnover costs in labor markets. 


\section{References}

Abraham, Katharine C., John C. Haltiwanger, Kristin Sandusky, and James R. Spletzer, "Measuring the Gig Economy: Current Knowledge and Open Issues," manuscript, University of Maryland, March 2, 2017.

Ball, Larry M. N. Gregory Mankiw and David Romer (1988), 'The New Keynesian Economics and the Output-Inflation Trade-off', Brookings Papers on Economic Activity 1, 1-65. https://doi.org/10.2307/2534424

Campbell, Carl (2017), “A Model of the Natural Rate of Unemployment and the Phillips Curve with Efficiency Wages, Bargaining, and Search and Matching," https://www.niu.edu/econ/about/directory/faculty/campbell/EW_Barg_Search0917.pdf

Cavallo, Alberto (2018), "More Amazon Effects: Online Competition and Pricing Behaviors,” National Bureau of Economic Research Working Paper 25138.

https://doi.org/10.3386/w25138

Duca, John V. and David D. VanHoose (2000), "Has Greater Competition Restrained U.S. Inflation?” Southern Economic Journal 66 (3), 729-41. https://doi.org/10.2307/1061435

Friedman, Milton (1968), “The Role of Monetary Policy,” American Economic Review 58 (March), 1-17.

Friedman, Milton (1977), “Nobel Lecture: Inflation and Unemployment,” Journal of Political Economy 85 (3), 451-72. https://doi.org/10.1086/260579

Fuhrer, Jeffrey C. (1995), “The Phillips Curve is Alive and Well," New England Economic Review of the Federal Reserve Bank of Boston (March/April), 41-56.

Gordon, Robert J. (1977), “Can the Inflation of the 1970s Be Explained?” Brookings Papers on Economic Activity 1, 253-76. https://doi.org/10.2307/2534262

Gordon, Robert J. (1997), “The time-varying NAIRU and its implications for economic policy,” Journal of Economic Perspectives 11, 11-32. https://doi.org/10.1257/jep.11.1.11

Guilloux-Nefussi, Sophie (2015), “Globalization, Market Structure, and the Flattening of the Phillips Curve,” Bank of France Working Paper 539.

Hall, Robert E. (2011), “The Long Slump,” American Economic Review 101 (2): 431-69. https://doi.org/10.1257/aer.101.2.431

Katz, Lawrence F. and Alan B. Krueger (2016), “The Rise and Nature of Alternative Work Arrangements in the United States, 1995-2015,” NBER Working Paper 22667. https://doi.org/10.3386/w22667 
Kleina, Lisa R. (1998), "Evaluating the Potential of Interactive Media through a New Lens: Search versus Experience Goods,” Journal of Business Research 3 (1), 195-203. https://doi.org/10.1016/s0148-2963(97)00062-3

Kuttner, Kenneth and Tim Robinson (2010), "Understanding the Flattening Phillips Curve," North American Journal of Economics and Finance 21 (2), 110-25. https://doi.org/10.1016/j.najef.2008.10.003

Michael, Steven C., (1994), "Competition in Organizational Form: Mail Order Versus Retail Stores, 1910- 1940,” Journal of Economic Behavior and Organization 23 (3), 269-286. https://doi.org/10.1016/0167-2681(94)90002-7

Phelps, Edmund S. (1967), "Phillips Curves, Expectations of Inflation, and Optimal Unemployment Over Time," Economica 35 (135), 254-281. https://doi.org/10.2307/2552025

Phelps, Edmund S. (1968), “Money-Wage Dynamics and Labor Market Equilibrium,” Journal of Political Economy 76 (July/August), 678-711. https://doi.org/10.1086/259438

Saving, Thomas R. (1970), "Concentration Ratios and the Degree of Monopoly Power," International Economic Review 11 (1), 139-46. https://doi.org/10.2307/2525343

Shapiro, Carl and Joseph E. Stiglitz (1984), "Equilibrium Unemployment as a Worker Discipline Device,” American Economic Review 74 (3): 433-444.

Staiger, Douglas, Stock, James H., and Watson, Mark W. (2001), "Prices, Wages, and the U.S. NAIRU in the 1990s," in: The Roaring Nineties: Can Full Employment Be Sustainable? Edited by Alan B. Krueger and Robert Solow, 3-60 (New York: Russell Sage Foundation; New York: Century Foundation Press).

Stiglitz, Joseph E. (1974), “Alternative Theories of Wage Determination and Unemployment in LDCs: The Labor Turnover Model,” Quarterly Journal of Economics 88 (2), 194-227. https://doi.org/10.2307/1883069

Sleuwaegen, Leo and Wim Dehandschutter (1986), "The Critical Choice Between the Concentration Ratio and the H-Index in Assessing Industry Performance,” Journal of Industrial Economics 35 (2), 193-208. 


\section{Appendix A: Pre-1999 Data on Online Retail Sales}

Using the NAICs-based industry code, the Census measures the share of retail sales conducted using mail order or electronic shopping for the period January 1993 to December 2000. This share equals 4.8 percent in 1999:q4. Subtracting the 0.6 percent online share for that quarter (Census data) implies that mail order sales comprised 4.2 percentage points of the 4.8 percent combined mail order and electronic share of retail sales. Assuming the mail order share was roughly constant in the quarters preceding 1999q4, 4.2 percentage points is subtracted from the combined mail order and electronic share. This yields readings of $0.0,0.1,0.1,0.2,0.3$, and 0.5 percentage points for $1998 q 2-1999 q 3$. The surveyed reading for $1999 q 4$ is 0.6 , implying a plausible rise of 0.1 percentage point in the online share from 1999q3, where the splice with surveyed data occurs. These pre1999:q4 data, in turn, are spliced onto official Census data (since 1999q4), providing a series running from 1998 to present. Readings before 1998q2 equal zero. 
Table 1: Gig Economy Models of Core PCE Inflation ${ }^{1}$

Full Sample

1962:q2-2018:q3

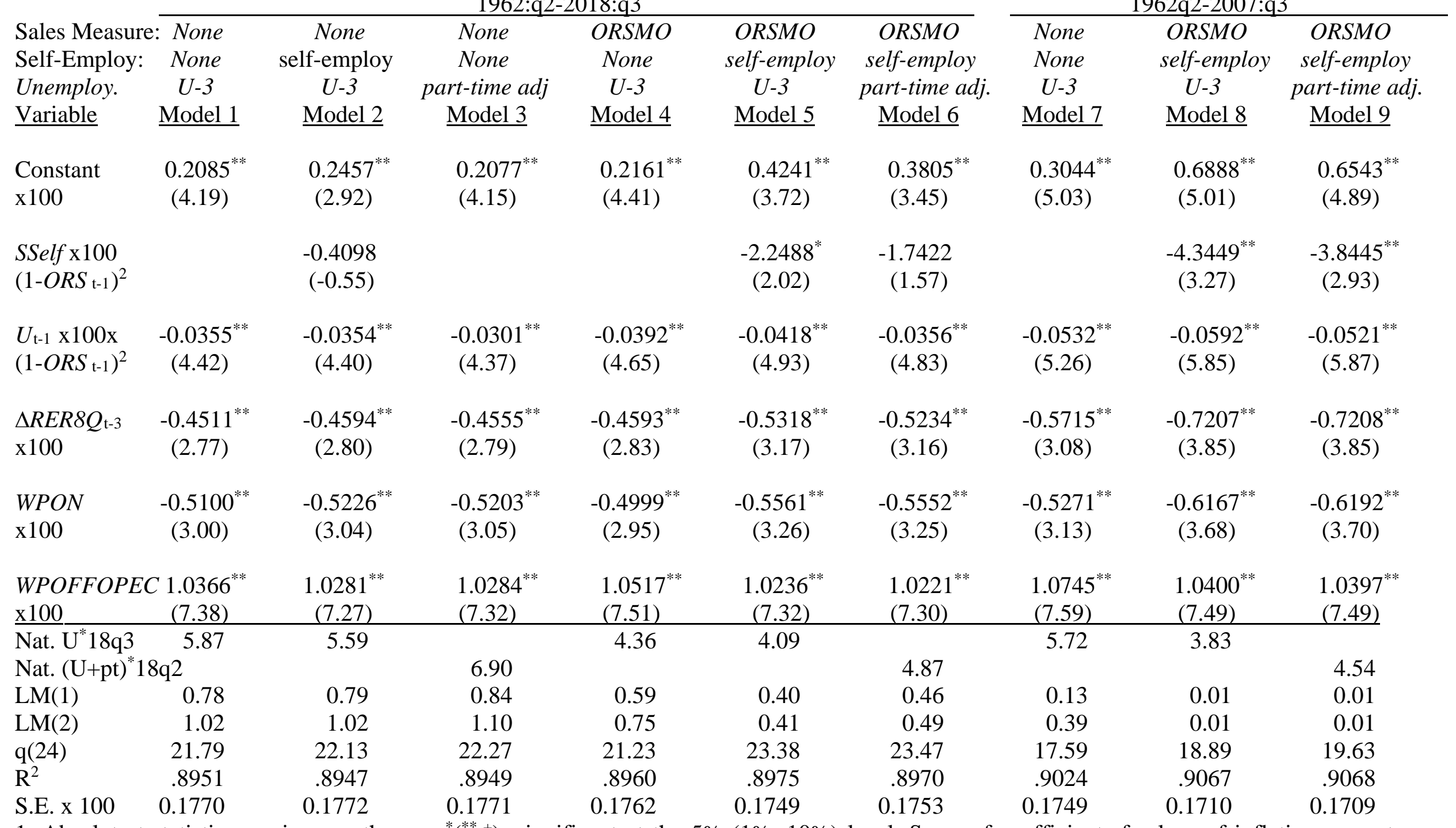

Pre-Great Recession

U-3

elf-employ

If-employ

self-employ

Unemploy. U-3

Model 2

rt-time adj

0.2161

0.3044

Model 8

art-time adj.

Constan

$0.2085^{* *}$

$0.2457^{* *}$

$0.2077^{* *}$

0.2161
$(4.41)$

$0.4241^{*}$

$(3.45)$

$(5.03)$

(5.01)

$0.6543^{* *}$

$-2.2488^{*} \quad-1.7422$

$-4.3449^{* *}$

$-3.8445^{* *}$

$.0532^{*}$

$0.0592^{* *}$

$0.0521^{* *}$

$(1-O R S \mathrm{t}-1)^{2}$

0.0355

0.0354

(4.37)

-0.0392
$(4.65)$

(4.93)

$.5715^{* *}$

$-0.7207^{* *}$

$\mathrm{x} 10$

0.4594

(2.83)

(3.17)

(3.16)

$-0.5271$

$-0.6167^{*}$

$(2.95)$

(3.26)

(3.25)

0.1709

1. Absolute t-statistics are in parentheses. ${ }^{*}\left({ }^{* *},+\right)$ : significant at the $5 \%(1 \%, 10 \%)$ level. Sums of coefficients for lags of inflation are not reported because the sum is constrained to $=1$. Nat. $U^{*}$ : natural rate of unemployment using estimated coefficients and is time-varying for the impact of productivity growth plus any time variation from self-employment and online sales. 
Table 2: Gig Economy Models of Market-Based Core PCE Inflation ${ }^{1}$

Full Sample

1962:q2-2018:q3

\begin{tabular}{|c|c|c|c|c|c|c|c|c|c|}
\hline & \multicolumn{6}{|c|}{ 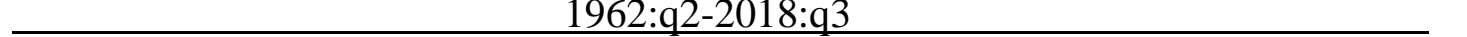 } & \multicolumn{3}{|c|}{$190 \angle \mathrm{q}<-\angle 00 /: \mathrm{q} 3$} \\
\hline $\begin{array}{l}\text { Sales Measure: } \\
\text { Self-Employ: } \\
\text { Unemploy. } \\
\text { Variable }\end{array}$ & $\begin{array}{c}\text { None } \\
\text { None } \\
\text { U-3 } \\
\text { Model 1 } \\
\end{array}$ & $\begin{array}{c}\text { None } \\
\text { self-employ } \\
U-3 \\
\text { Model } 2 \\
\end{array}$ & $\begin{array}{c}\text { None } \\
\text { None } \\
\text { part-time adj } \\
\text { Model } 3 \\
\end{array}$ & $\begin{array}{c}\text { ORSMO } \\
\text { None } \\
\text { U-3 } \\
\text { Model } 4 \\
\end{array}$ & $\begin{array}{c}\text { ORSMO } \\
\text { self-employ } \\
U-3 \\
\text { Model } 5 \\
\end{array}$ & $\begin{array}{c}\text { ORSMO } \\
\text { self-employ } \\
\text { part-time adj. } \\
\text { Model 6 }\end{array}$ & $\begin{array}{c}\text { None } \\
\text { None } \\
\text { U-3 } \\
\text { Model } 7 \\
\end{array}$ & $\begin{array}{l}\text { ORSMO } \\
\text { self-employ } \\
U-3 \\
\text { Model } 8 \\
\end{array}$ & $\begin{array}{c}\text { ORSMO } \\
\text { self-employ } \\
\text { part-time adj. } \\
\text { Model } 9 \\
\end{array}$ \\
\hline $\begin{array}{l}\text { Constant } \\
\text { x100 }\end{array}$ & $\begin{array}{c}0.1709^{* *} \\
(4.02)\end{array}$ & $\begin{array}{l}0.2044^{* *} \\
(2.96)\end{array}$ & $\begin{array}{l}0.1694^{* *} \\
(3.98)\end{array}$ & $\begin{array}{l}0.1728^{* *} \\
(4.11)\end{array}$ & $\begin{array}{l}0.3185^{* *} \\
(3.46)\end{array}$ & $\begin{array}{l}0.2835^{* *} \\
(3.19)\end{array}$ & $\begin{array}{l}0.2198^{* *} \\
(4.19)\end{array}$ & $\begin{array}{l}0.4571^{* *} \\
(4.09)\end{array}$ & $\begin{array}{l}0.4296^{* *} \\
(3.96)\end{array}$ \\
\hline $\begin{array}{l}\text { SSelf } \mathrm{x} 100 \\
\left(1-O R S_{\mathrm{t}-1}\right)^{2}\end{array}$ & & $\begin{array}{c}-0.3790 \\
(-0.62)\end{array}$ & & & $\begin{array}{c}-1.6004^{+} \\
(1.78)\end{array}$ & $\begin{array}{c}-1.1971 \\
(1.33)\end{array}$ & & $\begin{array}{c}-2.7821^{*} \\
(2.56)\end{array}$ & $\begin{array}{c}-2.4172^{*} \\
(2.25)\end{array}$ \\
\hline $\begin{array}{l}U_{\mathrm{t}-1} \mathrm{x} 100 \mathrm{x} \\
\left(1-O R S S_{\mathrm{t}-1}\right)^{2}\end{array}$ & $\begin{array}{c}-0.0293^{* *} \\
(4.28)\end{array}$ & $\begin{array}{c}-0.0291^{* *} \\
(4.23)\end{array}$ & $\begin{array}{c}-0.0247^{* *} \\
(4.23)\end{array}$ & $\begin{array}{l}-0.0316^{* *} \\
(4.37)\end{array}$ & $\begin{array}{c}-0.0330^{* *} \\
(4.56)\end{array}$ & $\begin{array}{c}-0.0280^{* *} \\
(4.44)\end{array}$ & $\begin{array}{c}-0.0386^{* *} \\
(4.41)\end{array}$ & $\begin{array}{l}-0.0412^{* *} \\
(4.71)\end{array}$ & $\begin{array}{c}-0.0358^{* *} \\
(4.67)\end{array}$ \\
\hline $\begin{array}{l}\Delta U_{\mathrm{t}-1} \mathrm{x} 100 \mathrm{x} \\
\left(1-O R S_{\mathrm{t}-1}\right)^{2}\end{array}$ & $\begin{array}{c}-0.0835^{*} \\
(2.49)\end{array}$ & $\begin{array}{c}-0.0854^{*} \\
(2.53)\end{array}$ & $\begin{array}{c}-0.0743^{* *} \\
(2.53)\end{array}$ & $\begin{array}{c}-0.0874^{*} \\
(2.44)\end{array}$ & $\begin{array}{c}-0.0895^{*} \\
(2.51)\end{array}$ & $\begin{array}{c}-0.0788^{*} \\
(2.51)\end{array}$ & $\begin{array}{c}-0.0967^{*} \\
(2.23)\end{array}$ & $\begin{array}{c}-0.1044^{*} \\
(2.44)\end{array}$ & $\begin{array}{c}-0.0932^{*} \\
(2.42)\end{array}$ \\
\hline $\begin{array}{l}\triangle R E R 8 Q_{\mathrm{t}-1} \\
\mathrm{x} 100\end{array}$ & $\begin{array}{c}-0.2992^{*} \\
(2.26)\end{array}$ & $\begin{array}{c}-0.3049^{*} \\
(2.30)\end{array}$ & $\begin{array}{l}-0.3021^{*} \\
(2.28)\end{array}$ & $\begin{array}{c}-0.3018^{*} \\
(2.28)\end{array}$ & $\begin{array}{c}-0.3440^{*} \\
(2.57)\end{array}$ & $\begin{array}{c}-0.3381^{*} \\
(2.53)\end{array}$ & $\begin{array}{c}-0.2233 \\
(1.45)\end{array}$ & $\begin{array}{c}-0.2997^{+} \\
(1.93)\end{array}$ & $\begin{array}{c}-0.2983^{+} \\
(1.92)\end{array}$ \\
\hline $\begin{array}{l}\text { WPON } \\
\mathrm{x} 100\end{array}$ & $\begin{array}{c}-0.5203^{* *} \\
(3.69)\end{array}$ & $\begin{array}{c}-0.5317^{* *} \\
(3.73)\end{array}$ & $\begin{array}{l}-0.5291^{* *} \\
(3.73)\end{array}$ & $\begin{array}{c}-0.5124^{* *} \\
(3.64)\end{array}$ & $\begin{array}{c}-0.5526^{* *} \\
(3.90)\end{array}$ & $\begin{array}{c}-0.5523^{* *} \\
(3.88)\end{array}$ & $\begin{array}{c}-0.5149^{* *} \\
(3.62)\end{array}$ & $\begin{array}{c}-0.5702^{* *} \\
(4.00)\end{array}$ & $\begin{array}{c}-0.5722^{* *} \\
(4.01)\end{array}$ \\
\hline $\begin{array}{l}\text { WPOFFOPEC } \\
\mathrm{x} 100\end{array}$ & $\begin{array}{l}0.9296^{* *} \\
(8.15)\end{array}$ & $\begin{array}{l}0.9224^{* *} \\
(8.03)\end{array}$ & $\begin{array}{l}0.9230^{* *} \\
(8.09)\end{array}$ & $\begin{array}{l}0.9390^{* *} \\
(8.24)\end{array}$ & $\begin{array}{l}0.9206^{* *} \\
(8.09)\end{array}$ & $\begin{array}{l}0.9192^{* *} \\
(8.06)\end{array}$ & $\begin{array}{l}0.9082^{* *} \\
(7.79)\end{array}$ & $\begin{array}{l}0.8857^{* *} \\
(7.66)\end{array}$ & $\begin{array}{l}0.8852^{* *} \\
(7.65)\end{array}$ \\
\hline Nat. $U^{*} 18 q 2$ & 5.83 & 5.50 & 6.86 & 4.32 & 4.09 & 4.88 & 5.69 & 5.68 & 3.84 \\
\hline $\mathrm{LM}(1)$ & 0.36 & 0.35 & 0.34 & 0.28 & 0.14 & 0.14 & 0.39 & 0.10 & 0.07 \\
\hline LM(2) & 0.42 & 0.43 & 0.37 & 0.36 & 0.48 & 0.35 & 0.68 & 1.25 & 1.01 \\
\hline $\mathrm{q}(24)$ & 24.99 & 25.40 & 25.34 & 24.41 & 27.43 & 27.22 & 19.81 & 23.18 & 23.15 \\
\hline $\mathrm{R}^{2}$ & .9326 & .9324 & .9324 & .9329 & .9336 & .9333 & .9347 & .9362 & .9361 \\
\hline S.E. $x 100$ & 0.1462 & 0.1464 & 0.1463 & 0.1458 & 0.1451 & 0.1454 & 0.1469 & 0.1452 & 0.1453 \\
\hline
\end{tabular}

1. Absolute t-statistics are in parentheses. ${ }^{*}\left({ }^{* *},+\right)$ : significant at the $5 \%(1 \%, 10 \%)$ level. Sums of coefficients for lags of inflation are not reported because the sum is constrained to $=1$. Nat. $U^{*}$ : natural rate of unemployment using estimated coefficients and is time-varying for the impact of productivity growth (hp for calculation) plus any time variation from self-employment and online sales. 
Table 3: Gig Economy Models of Inflation: Self-Employment Tracked With Self-Employment Taxes ${ }^{1}$

(common sample period, 1978:q1-2018:q3)

Price Index:

Sales Measure: None

Core PCE

Self-Employ. None self-employ None self-employ

\begin{tabular}{lccc}
\multicolumn{4}{c}{ Market-Based Core PCE } \\
\hline None & None & ORSMO & ORSMO \\
None & self-employ & None & self-employ
\end{tabular}

$\underline{\text { Variable }} \underline{\text { Model } 1} \quad \underline{\text { Model } 2} \quad \underline{M o d e l ~} 3 \quad \underline{M o d e l ~ 4} \quad \underline{\text { Model } 5} \quad \underline{\text { Model } 6} \quad \underline{\text { Model } 7} \quad \underline{\text { Model } 8}$

$\begin{array}{lccllllll}\text { Constant } & 0.0978 & 0.0764 & 0.1130^{+} & 0.3452^{+} & 0.0944^{+} & 0.1413 & 0.0970^{*} & 0.3765^{*} \\ \text { x100 } & (1.59) & (0.59) & (1.90) & (1.68) & (1.90) & (1.39) & (2.02) & (2.35)\end{array}$

x100

(1.59)

(0.59)

(1.90)

(1.68)

$(1.90)$

(1.39)

(2.02)

(2.35)

SSelf $\mathrm{x} 100$

$0.1992-2.2310$

$-0.4352$

$-2.6822^{+}$

$\left(1-O R S_{\mathrm{t}-1}\right)^{2}$

(0.19)

(1.19)

(0.53)

(1.83)

$\begin{array}{lcccccccc}U_{\mathrm{t}-1 \mathrm{X}} & -0.0181^{+} & -0.0178^{+} & -0.0223^{*} & -0.0276^{*} & -0.0168^{*} & -0.0174^{*} & -0.0186^{*} & -0.0249^{* *} \\ (1-O R S & \mathrm{t}-1)^{2} & (1.86) & (1.81) & (2.18) & (2.48) & (2.13) & (2.18) & (2.25)\end{array}$

$\Delta U_{\mathrm{t}-1}$

$\mathrm{x} 100$

$\begin{array}{llll}-0.0855^{*} & -0.0866^{*} & -0.0906^{*} & -0.0883^{*}\end{array}$

(2.37) (2.39) (2.33)

$\begin{array}{lcccccrrr}\triangle R E R 8 Q_{\mathrm{t}-1} & -0.4072^{*} & -0.4032^{*} & -0.4211^{*} & -0.5022^{*} & -0.3067^{*} & -0.3168^{*} & -0.3081^{*} & -0.4037^{* *} \\ \text { x100 } & (2.38) & (2.33) & (2.47) & (2.73) & (2.35) & (2.39) & 4.36) \\ \text { Nat. U*18q2 } & 5.40 & 5.60 & 4.00 & 3.98 & 5.62 & 5.41 & 4.12 & 4.09 \\ \text { LM(1) } & 2.34 & 2.33 & 2.22 & 2.12 & 0.07 & 0.05 & 0.09 & 0.06 \\ \text { LM(2) } & 2.35 & 2.34 & 2.22 & 2.25 & 0.28 & 0.27 & 0.26 & 0.22 \\ \text { q(24) } & 13.67 & 13.82 & 14.17 & 13.54 & 14.56 & 14.35 & 14.61 & 14.79 \\ \text { R }^{2} & .8799 & .8792 & .8809 & .8813 & .9337 & .9334 & .9340 & .9350 \\ \text { S.E. x } 100 & 0.1763 & 0.1769 & 0.1755 & 0.1753 & 0.1382 & 0.1386 & 0.1379 & 0.1369\end{array}$

1. Absolute t-statistics are in parentheses. ${ }^{*}\left({ }^{* *},+\right)$ : significant at the $5 \%(1 \%, 10 \%)$ level. Sums of coefficients for lags of inflation are not reported because the sum is constrained to $=1$. "Nat. $\mathrm{U}^{*}$ " is the natural rate of unemployment implied by estimated coefficients. 
Table 4: Gig Economy Models of Employment Cost Inflation'

Full Sample

1982:q2-2018:q3

\begin{tabular}{|c|c|c|c|c|c|c|c|c|c|}
\hline \multirow[b]{2}{*}{$\begin{array}{l}\text { Sales Measure: } \\
\text { Self-Employ: } \\
\text { Unemploy. } \\
\text { Variable }\end{array}$} & \multicolumn{6}{|c|}{$190<.4<-2010.43$} & \multicolumn{3}{|c|}{$190<.4<-\angle 00 / .40$} \\
\hline & $\begin{array}{c}\text { None } \\
\text { None } \\
\text { U-3 } \\
\text { Model } 1\end{array}$ & $\begin{array}{c}\text { None } \\
\text { self-employ } \\
U-3 \\
\text { Model } 2\end{array}$ & $\begin{array}{c}\text { None } \\
\text { None } \\
\text { part-time adj } \\
\text { Model } 3\end{array}$ & $\begin{array}{c}\text { ORSMO } \\
\text { None } \\
\text { U-3 } \\
\text { Model } 4 \\
\end{array}$ & $\begin{array}{c}\text { ORSMO } \\
\text { self-employ } \\
U-3 \\
\text { Model } 5 \\
\end{array}$ & $\begin{array}{c}\text { ORSMO } \\
\text { self-employ } \\
\text { part-time adj. } \\
\text { Model } 6\end{array}$ & $\begin{array}{c}\text { None } \\
\text { None } \\
\text { U-3 } \\
\text { Model } 7 \\
\end{array}$ & $\begin{array}{c}\text { ORSMO } \\
\text { self-employ } \\
U-3 \\
\text { Model } 8 \\
\end{array}$ & $\begin{array}{c}\text { ORSMO } \\
\text { self-employ } \\
\text { part-time adj. } \\
\text { Model } 9\end{array}$ \\
\hline $\begin{array}{l}\text { Constant } \\
\text { x100 }\end{array}$ & $\begin{array}{c}0.4472^{* *} \\
(6.80)\end{array}$ & $\begin{array}{c}0.5077^{* *} \\
(2.95)\end{array}$ & $\begin{array}{l}0.4604^{* *} \\
(6.84)\end{array}$ & $\begin{array}{l}0.4307^{* *} \\
(6.81)\end{array}$ & $\begin{array}{l}1.1972^{* *} \\
(4.13)\end{array}$ & $\begin{array}{l}1.0958^{* *} \\
(3.82)\end{array}$ & $\begin{array}{l}0.5267^{* *} \\
(4.39)\end{array}$ & $\begin{array}{l}1.8911^{* *} \\
(3.79)\end{array}$ & $\begin{array}{l}1.8644^{* *} \\
(3.79)\end{array}$ \\
\hline $\begin{array}{l}\text { SSelf } \mathrm{x} 100 \\
(1-O R S \mathrm{t}-1)^{2}\end{array}$ & & $\begin{array}{c}-0.5636 \\
(-0.38)\end{array}$ & & & $\begin{array}{c}-7.9388^{* *} \\
(2.70)\end{array}$ & $\begin{array}{c}-6.7139^{*} \\
(2.30)\end{array}$ & & $\begin{array}{c}-13.8350^{* *} \\
(2.84)\end{array}$ & $\begin{array}{c}-13.2822^{* *} \\
(2.76)\end{array}$ \\
\hline $\begin{array}{l}U_{\mathrm{t}-1} \mathrm{x} \\
\left(1-O R S_{\mathrm{t}-1}\right)^{2}\end{array}$ & $\begin{array}{c}-0.0647^{* *} \\
(6.70)\end{array}$ & $\begin{array}{c}-0.0647^{* *} \\
(6.67)\end{array}$ & $\begin{array}{c}-0.0552^{* *} \\
(6.75)\end{array}$ & $\begin{array}{c}-0.0691^{* *} \\
(6.71)\end{array}$ & $\begin{array}{c}-0.0717^{* *} \\
(7.10)\end{array}$ & $\begin{array}{c}-0.0614^{* *} \\
(7.09)\end{array}$ & $\begin{array}{c}-0.0768^{* *} \\
(4.19)\end{array}$ & $\begin{array}{c}-0.0952^{* *} \\
(5.13)\end{array}$ & $\begin{array}{c}-0.0835^{* *} \\
(5.20)\end{array}$ \\
\hline $\begin{array}{l}\Delta U_{\mathrm{t}-1} \\
\mathrm{x} 100\end{array}$ & $\begin{array}{c}-0.1461^{* *} \\
(2.68)\end{array}$ & $\begin{array}{c}-0.1443^{* *} \\
(2.62)\end{array}$ & $\begin{array}{c}-0.1313^{* *} \\
(2.74)\end{array}$ & $\begin{array}{c}-0.1627^{* *} \\
(2.75)\end{array}$ & $\begin{array}{c}-0.1444^{*} \\
(2.48)\end{array}$ & $\begin{array}{c}-0.1315^{*} \\
(2.55)\end{array}$ & $\begin{array}{c}-0.1057 \\
(1.28)\end{array}$ & $\begin{array}{c}-0.1199 \\
(1.46)\end{array}$ & $\begin{array}{r}-0.1038 \\
(1.39)\end{array}$ \\
\hline $\begin{array}{l}\Delta \operatorname{Prod}_{8 Q_{\mathrm{t}-1}} \\
\mathrm{x} 100\end{array}$ & $\begin{array}{l}0.0895^{* *} \\
(6.38)\end{array}$ & $\begin{array}{c}0.0881^{* *} \\
(6.30)\end{array}$ & $\begin{array}{l}0.0863^{* *} \\
(6.45)\end{array}$ & $\begin{array}{c}0.0937^{* *} \\
(6.96)\end{array}$ & $\begin{array}{c}0.0894^{* *} \\
(6.75)\end{array}$ & $\begin{array}{l}0.0872^{* *} \\
(6.60)\end{array}$ & $\begin{array}{c}0.0869^{* *} \\
(4.62)\end{array}$ & $\begin{array}{l}0.0807^{* *} \\
(4.44)\end{array}$ & $\begin{array}{c}0.0785^{* *} \\
(4.32)\end{array}$ \\
\hline $\begin{array}{l}\triangle P \text { Energy8Q } \mathrm{t}-1 \\
\mathrm{x} 100\end{array}$ & $\begin{array}{c}-1-0.5737^{* *} \\
(5.15)\end{array}$ & $\begin{array}{c}-0.5707^{* *} \\
(5.09)\end{array}$ & $\begin{array}{l}-0.5784^{* *} \\
(5.18)\end{array}$ & $\begin{array}{c}-0.5763^{* *} \\
(5.16)\end{array}$ & $\begin{array}{c}-0.5368^{* *} \\
(4.88) \\
\end{array}$ & $\begin{array}{c}-0.5488^{* *} \\
(4.97) \\
\end{array}$ & $\begin{array}{c}-0.5676^{* *} \\
(3.20)\end{array}$ & $\begin{array}{c}-0.5219^{* *} \\
(2.97)\end{array}$ & $\begin{array}{c}-0.5434^{* *} \\
(3.07)\end{array}$ \\
\hline Nat. U*18q3 & 5.23 & 5.17 & & 4.93 & 3.91 & & 5.48 & 4.27 & \\
\hline Nat. $(U+p t)^{*} 18 c$ & qq3 & & 6.26 & & & 4.72 & & & 5.13 \\
\hline $\mathrm{LM}(1)$ & 3.09 & 3.01 & 2.82 & 3.19 & 1.04 & 1.02 & 2.36 & 0.32 & 0.20 \\
\hline $\mathrm{LM}(2)$ & 3.53 & 3.46 & 3.20 & 3.57 & 1.07 & 1.04 & 2.44 & 0.45 & 0.42 \\
\hline$q(24)$ & 19.15 & 18.83 & 19.12 & 17.33 & 11.54 & 11.95 & 17.16 & 11.79 & 11.56 \\
\hline $\mathrm{R}^{2}$ & .6741 & .6720 & .6746 & .6738 & .6885 & .6893 & .4783 & .5189 & .5218 \\
\hline S.E. x 100 & 0.1760 & 0.1766 & 0.1753 & 0.1761 & 0.1721 & 0.1718 & 0.1935 & 0.1859 & 0.1853 \\
\hline
\end{tabular}

1. Absolute t-statistics are in parentheses. ${ }^{*}\left({ }^{* *+},\right)$ : significant at the $5 \%(1 \%, 10 \%)$ level. Sums of coefficients for lags of inflation are not reported because the sum is constrained to $=1$. Nat. $U^{*}$ : natural rate of unemployment using estimated coefficients and is time-varying for the impact of productivity growth (hp for calculation) plus any time variation from self-employment and online sales.

Pre-Great Recession

1982:a2-2007:q3 self-employ rt-time adj U-3 rt-time adj. U-3 U-3 art-time adj.

$.8644^{* *}$

0.4307
$(6.81)$

1.1972

1.0958

.5267
$(4.39)$

(3.79)

$$
\text { (2.76) }
$$

$0835^{* *}$ 